\title{
Phonological Awareness and Vocabulary Characteristics of Children with Speech Sound Disorders
}

\author{
Eun-Young Seo ${ }^{\mathrm{a}}$, Yoo-Kyeong Ko ${ }^{\mathrm{a}}$, Gyung-Ah Oh${ }^{\mathrm{a}}$, Soo-Jin Kim ${ }^{\mathrm{b}}$ \\ a'Department of Communication Disorders, The Graduate School of Korea Nazarene University, Cheonan, Korea \\ ${ }^{b}$ Department of Communication Disorders, Korea Nazarene University, Cheonan, Korea
}

Correspondence: Soo-Jin Kim, PhD Department of Communication Disorders, Korea Nazarene University, 48 Wolbong-ro, Seobuk-gu, Cheonan 31172, Korea

Tel: $+82-41-570-7978$

Fax: $+82-41-570-7846$

E-mail: sjkim@kornu.ac.kr

Received: April 5, 2017

Revised: May 16, 2017

Accepted: May 26, 2017

\begin{abstract}
Objectives: Phonological awareness (PA) skills and vocabulary knowledge are known to be significant predictors of later reading and literacy skills. There have been inconsistent reports about PA, characteristics of vocabulary, and their influences on literacy for children with speech sound disorders (SSD). The aim of this study is to investigate whether there are any differences in PA and vocabulary skills between SSD children and typically developing children (TD). Methods: The subjects were 24 TD children and 24 SSD children between 5 and 6 years old. These children were tested on articulation ability (percentage of correct consonants [PCC]), PA, and vocabulary skills. Results: The results are as follows. First, statistically significant differences were found in PA and vocabulary skills between age groups and SSD/TD groups. Second, PA skills had a stronger correlation with vocabulary knowledge than articulation ability (PCC). Thirty-three percent of SSD children showed delay in both PA and vocabulary. Sixteen percent of SSD children showed delay in phonological awareness only, and $16 \%$ of SSD showed delay in vocabulary skills only. Lastly, 33\% of SSD children were considered to be pure SSD with no delay in any tested area. Conclusion: The researchers suggest that differential evaluation and intervention are crucial for SSD children with accompanying difficulties in PA and vocabulary skills. For SSD children with delay in PA and/or vocabulary skills, direct intervention and continued monitoring of early literacy skills should be required to prevent potential future literacy difficulties.
\end{abstract}

Keywords: Speech sound disorder, Phonological awareness, Vocabulary, Literacy skill
말소리장애 중 원인을 모르는 말소리장애는 원인이 분명한 경우 를 제외한 것으로 다양한 원인에 의해 발생하고 동반하고 있는 문 제의 유무나 특성, 말소리의 증상, 말 처리 과정 등이 다양한 이질적 인 집단이다. 이러한 이질적인 집단을 하위 유형으로 분류하고 특 성을 밝혀내고자 노력하는 이유는 치료 예후를 예측하고 차별적인 평가 및 중재 접근을 적용하는데 중요하기 때문이다. 특히 이질적 인 말소리장애 집단의 동반 문제를 파악하는 것은 문제의 특성을 확인하고 동반하고 있는 문제들 사이의 관계를 이해함으로써 궁극 적으로 중재에 적용하기 위해서 고려되어야 한다(Bernthal, Bankson, \& Flipson, 2013).

원인을 모르는 말소리장애의 경우에도 말소리 산출상의 문제만
을 보이는 경우는 드물고 인지, 심리, 사회, 의사소통 등의 문제를 동반하고 있는 경우가 많으며 의사소통 문제 중 언어, 음성, 유창성 문제가 동반 문제로 나타날 수 있다. 말소리장애 아동이 가장 빈번 하게 동반하고 있는 문제로는 언어 문제가 있으며 어휘, 음운인식, 문해 기술 등에서도 어려움을 보일 수 있다(Kim, Kim, Ha, \& Ha, 2015). 특히 언어와 어휘, 음운인식 문제가 언급되는 이유는 말소리 장애 아동의 이후 문해 기술을 예측하고 문해 문제를 예방하는데 중요한 요인이기 때문이다. 학령전기의 말소리장애 아동은 읽기와 철자 발달에 중요한 기술인 음운인식에 위험을 보일 가능성이 크고 이러한 어려움이 학령기 이후에도 지속될 수 있다(Preston, Hull, \& Edwards, 2013). 
음운인식은 단어의 소리 구조에 대한 인식을 포함하는 상위언어 적 기술로 음운표상의 질과 관련이 있다. 학령전기 음운인식 기술 은 학령기의 읽기와 철자를 예측할 수 있고 읽기 해독, 이해, 유창성 등과 관련이 있다(Bradley \& Bryant, 1983). 음운인식은 음절과 같 은 큰 음운 단위에서 초성이나 각운과 같은 중간 단위를 거쳐 음절 의 초성, 종성을 포함하는 개별적인 음소에 대한 인식으로 발달한 다(Rvachew \& Grawburg, 2006). 음운인식을 평가하는 방법은 주 로 단어의 음절이나 음소 수준에 대한 변별, 합성, 탈락과제를 포함 한다. 특히 탈락과제는 단어 내에 포함된 음소에 대하여 보다 직접 적인 조작과 분리를 요구하는 과제이며 일반아동과 말, 언어장애 혹은 말과 언어장애를 동반하고 있는 6세 아동을 변별해 주는 것 으로 나타났다(Leitao, Hogben, \& Fletcher, 1997). 또한 음운인식 과제 중에서 탈락과제가 읽기 성취를 가장 잘 예측하며 이후 읽기 와 가장 관련이 높은 것으로 나타났다(Catts, 1993; Torgesen, Wagner, \& Rashotte, 1994; Yopp, 1988).

음운인식능력이 부족한 아동은 초기 문해 기술의 문제를 보일 수 있는데(Preston et al., 2013) 말소리장애 아동의 말소리 산출의 어려움과 이후 음운인식, 문해 기술에서의 결함 사이에 유의한 상 관관계가 지속적으로 보고되고 있다(Bird, Bishop, \& Freeman, 1995; Dodd, 2005; Gillon, 2002; Rvachew, Ohberg, Grawburg, \& Heyding, 2003; Snowling, Bishop, \& Stothard, 2000). 또한 음운표 상의 질은 말소리 산출에도 영향을 미치기 때문에(Preston \& Edwards, 2010) 말소리장애 아동은 음운표상에 대한 질이나 접근성 이 약하다는 것을 알 수 있다(Anthony et al., 2011; Lewis, Freebairn, \& Taylor, 2002). 그러나 모든 말소리장애 아동이 음운인식이나 이 후 문해 기술을 습득하는데 어려움을 보이지 않으므로(Rvachew, 2007) 말소리장애 아동이 문해 기술에 어려움을 보이는가를 예측 하는 요인이나 위험 요인을 파악하는 것이 중요하다.

말소리장애 아동의 음운인식 및 이후 문해 기술에 영향을 주는 요인으로 연령, 자음정확도, 어휘력, 말지각 능력, 말소리 오류의 유 형, 심각도 등이 선행연구에 언급되고 있다. 연령의 측면에서 일반 적으로 음운인식은 아동의 연령이 증가하면서 발달하고 점차 안정 화되며(McDowell, Lonigan, \& Goldstein, 2007) 연령은 음운인식 과 유의한 상관관계가 있다(Foy \& Mann, 2001). 말소리 오류 유형 의 측면에서 특이한 오류 패턴을 일관적으로 사용하는 아동은 특 히 읽기상의 어려움을 보일 수 있다(Dodd, 2005). 또한 학령전기에 비전형적 오류를 보이는 말소리장애 아동은 음운인식능력이 더 약 한 것으로 나타났으며, 이는 비전형적인 음운 오류를 산출하는 것 이 약한 음운표상을 반영하는 것이다(Leitao, Hogben, \& Fletcher, 2004; Preston \& Edward, 2010). 비전형적 음운 오류를 보이는 말소
리장애 아동의 $93 \%$ 가 음운인식에 어려움을 보인다는 연구도 있다 (Broomfield \& Dodd, 2004). 어휘의 측면에서 학령전기 어휘 발달 의 크기와 특성이 음운인식 발달에 영향을 주고(Burgess \& Lonigan, 1998; Hemphill \& Tivnan, 2008) 이후 문해 기술을 예측하는 중요한 요인이며(Lonigan, Burgess, Anthony, \& Barker, 1998; Metsala \& Walley, 1998) 이것은 말소리장애 아동에게도 해당한다(Rvachew \& Grawburg, 2006). 말지각의 측면에서 음운인식능력과 관 련하여 말지각과 음운표상의 어려움이 말소리장애의 원인 요인이 라는 것을 제안하기도 하였다(Forrest, Chin, Pisoni, \& Barlow, 1994; Munson, Edwards, \& Beckman, 2005). 자음정확도의 측면에서 자 음정확도와 음운인식 및 읽기 능력에 대한 많은 연구들은 자음정 확도 단독으로는 음운인식과 유의한 상관관계가 없고 말소리 오류 의 유형이나 동반하고 있는 문제에 따라 다르다는 것을 보고하였 다. 언어장애를 동반하고 있는 말소리장애 아동이 언어장애를 동 반하지 않은 말소리장애 아동 보다 더 약한 음운인식을 보인다는 것은 많은 연구를 통해 입증하였다(Bird et al., 1995; Preston \& Edwards, 2010). 그러나 말소리장애 아동의 음운인식과 이후 문해 기 술에 영향을 미치는 요인들에서 어려움을 보이지 않은 말소리 문제 만을 보이는 아동도 음운인식이나 읽기장애를 보이기도 하므로 (Anthony et al., 2011) 이러한 요인들 간의 관계를 파악하고 하위 유 형으로 분류함으로써 각 하위 유형에 적절한 평가 및 중재 접근이 필요하다.

말소리장애 아동이 음운인식과 어휘에 지연을 보이는 비율을 살 펴본 이전 연구들은 그 비율에 있어 상당히 큰 차이를 보이고 있다. St. Louis, Ruscello와 Lundeen (1992)은 말소리장애 중 41\%가 다른 의사소통 문제를 동반하지 않는다고 보고하였다. 말소리장애 아동 이 음운인식에 지연을 보이는 비율에 대해 $28 \%$ 가 지연을 보인다고 보고한 연구도 있고(Preston \& Edwards, 2010) 학령전기에 말소리 장애 이력이 있고 초기 학령기에 부족한 읽기를 보이는 아동의 비 율을 77\% 혹은 60\% 등으로 다양하게 보고하고 있다(Bird et al., 1995; Larrivee \& Catts, 1999). 말소리장애 아동이 어휘에 지연을 보 이는 비율에 대해 $50 \%$ 가 지연을 보인다고 보고한 연구도 있다(Dodd, 2005). 국내에서는 최근에 말소리장애 집단을 하위 유형으로 분류 하거나 그 특성을 파악하고자 하는 노력을 보이고 있지만 직접적인 평가를 통해 실제로 그 관계를 밝히거나 하위 유형으로 분류한 바 는 없다.

연구문제는 다음과 같다. 첫째, 연령과 말소리장애 유무에 따른 음운인식과 어휘 능력의 차이를 살펴보고 둘째, 음운인식, 어휘, 자 음정확도 간 상관관계를 살펴보고 셋째, 말소리장애 아동이 음운 인식과 어휘에서 지연을 보이는 비율을 제시하고자 하였다. 


\section{연구방법}

\section{연구대상}

서울과 경기, 충남, 제주 지역에 거주하는 5,6 세 일반 아동과 말 소리장애 아동들로 각 연령집단별 12 명씩 총 48 명을 대상으로 하 였다. 대상자 정보는 Table 1과 같다. 일반 아동은 부모, 어린이집/유 치원 선생님의 보고에 의하면 (1) 일반적인 발달을 하고, (2) 장애가 없으며, (3) 수용·표현어휘력검사(REVT; Kim, Hong, Kim, Jang, \& Lee, 2009) 중 수용어휘력검사에서 $10 \%$ ile 이상으로 언어발달에 문 제가 없었다. 말소리장애 아동은 (1) 사설 언어치료실, 복지관 등에 서 언어재활사로부터 말소리장애로 진단받은 아동들로, (2) '아동 용 발음 평가(APAC; Kim, Pae, \& Park, 2007)'에서 10\%ile 이하에 속하였으며, 3) 음운인식 평가나 중재를 받은 이력이 없었다. 두 집 단 아동 모두 부모, 어린이집/유치원 선생님으로부터 청력, 정서, 인 지, 사회성에 문제가 없다고 보고된 아동이다.

\section{도구}

음운인식과제는 Oh, Seo, Ko와 Kim (2016)의 단어 및 음절탈락 과제를 이용하였다. 과제는 총 20 문항으로 구성되었고 연습 단계 3 문항을 포함하였다. 음운인식과제는 Appendix 1과 같다. 검사는 연속된 5 문항에서 실패하면 종료하였으며 음운인식점수는 정반응

Table 1. Participants' characteristics

\begin{tabular}{lcl}
\hline & Age $(y r)$ & \multicolumn{1}{c}{ PCC } \\
\hline TD group ( $N=12)$ & 5 & $99.8(0.4)$ \\
SSD group ( $N=12)$ & 6 & $98.9(1.2)$ \\
& 5 & $85.2(11.2)$ \\
& 6 & $86.2(8.0)$ \\
\hline
\end{tabular}

Values are presented as mean (SD).

$\mathrm{TD}=$ typically developing children; $S S D$ = speech sound disorders with unknown origin; $\mathrm{PCC}=$ percentage of correct consonants.
한 문항의 수로 계산하였다. 말소리 능력을 살펴보기 위해 APAC을 사용하였고 아동의 모든 반응은 녹음기를 통해 녹음하였으며 녹 음된 발화를 듣고 전사하여 채점하였다. 어휘력을 살펴보기 위해 REVT 중 수용어휘력검사를 사용하였으며 원점수와 백분위 점수 로 결과를 산출하였다.

\section{절차}

일반 아동과 말소리장애 아동을 대상으로 말소리, 어휘, 음운인 식과제 순으로 평가를 진행하였으며 각 아동당 평가에 소요된 시 간은 총 40 분이었다. 일반 아동은 아동이 재원 중인 유치원내 개별 적으로 검사가 가능한 공간에서 실시하였고 말소리장애 아동은 아동이 다니고 있는 복지관 및 언어치료실 내 개별적으로 검사가 가능한 공간에서 실시하였다. 총 자료 수집 기간은 1 년이 소요되었 으며 모든 평가는 평가 후 1 일이 지나기 전에 채점하였다. 말소리장 애 아동의 음운인식 지연 비율은 $\mathrm{Oh}$ 등(2016)에서 제시한 5,6 세 일 반아동의 음운인식점수를 기준으로 하였다.

\section{통계분석}

연령과 말소리장애 유무에 따른 음운인식, 어휘 능력의 차이를 살펴보기 위해 다변량 분석을 실시하였다. 음운인식과 자음정확도 및 어휘력의 상관관계를 살펴보기 위해서 상관분석을 실시하였다.

Table 2. Phonological awareness and vocabulary

\begin{tabular}{lccl}
\hline & Age (yr) & PA & Vocabulary \\
\hline TD group (N=12) & 5 & $9.25(6.9)$ & $63.50(13.6)$ \\
& 6 & $15.08(5.2)$ & $80.92(9.9)$ \\
SSD group (N=12) & 5 & $3.75(5.9)$ & $52.75(16.4)$ \\
& 6 & $11.25(6.4)$ & $63.75(18.6)$ \\
\hline
\end{tabular}

Values are presented as mean (SD).

$T D$ = typically developing children; SSD = speech sound disorders with unknown origin; $\mathrm{PA}=$ phonological awareness.
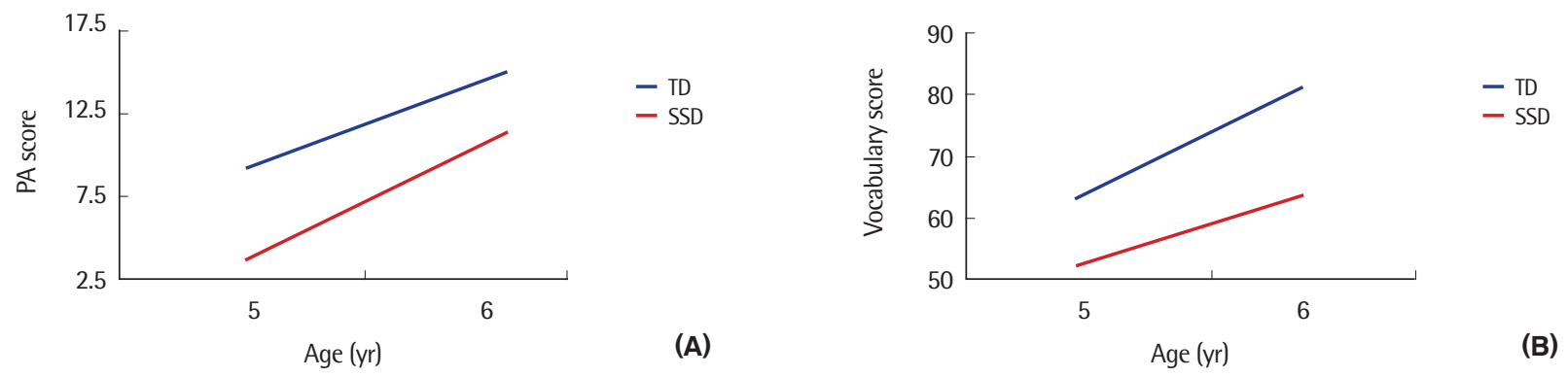

Figure 1. (A) Phonological awareness (PA) and (B) vocabulary scores according to age and disorders.

$\mathrm{TD}=$ typically developing children; SSD = speech sound disorders with unknown origin. 


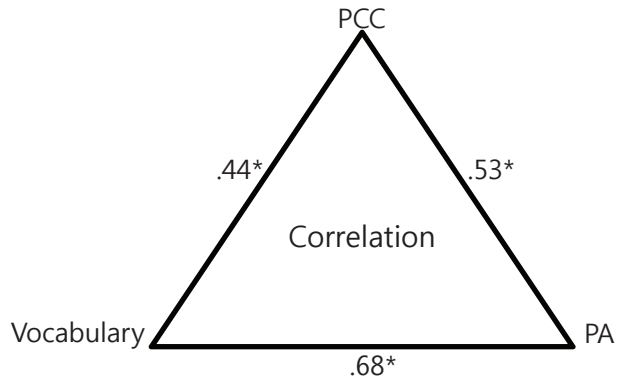

Figure 2. Correlation of phonological awareness (PA), vocabulary, and percentage of correct consonants (PCC). ${ }^{*} p<.001$.

\section{연구결과}

\section{연령과 말소리장애 유무에 따른 음운인식과 어휘 능력}

연령과 말소리장애 유무에 따른 음운인식, 어휘력 점수의 평균 과 표준편차는 Table 2, Figure 1과 같다. 음운인식과 어휘 능력의 차이를 살펴보기 위해 다변량 분석을 실시한 결과 연령 $\left(F_{(3,44)}=6.4\right.$, $p<.001)$ 과 말소리장애 유무 $\left(F_{(3,44)}=14.7, p<.001\right)$ 에 따라 통계적 으로 유의한 차이가 나타났지만 연령과 말소리장애 요인의 상호작 용 효과는 통계적으로 유의하지 않았다 $\left(F_{(3,44)}=.6, p>.05\right)$. 연령이 높을수록 음운인식과 어휘 능력이 높았으며 말소리장애 아동은 음운인식과 어휘에서 어려움을 보였다.

\section{음운인식, 자음정확도, 어휘 능력 간의 상관관계}

음운인식, 자음정확도, 어휘 능력 간의 상관관계를 살펴보기 위 해 Pearson 상관분석을 실시한 결과는 Figure 2와 같다. 음운인식, 자음정확도, 어휘 능력 간 상관관계가 통계적으로 유의한 것으로 나타났으며 특히 음운인식과 어휘력 간의 상관이 높은 것으로 나 타났다.

\section{말소리장애 아동의 음운인식과 어휘 능력 지연 비율}

말소리장애 아동 중 음운인식과 어휘에 지연을 보이지 않은 아 동은 24 명 중 8 명(33\%)으로 나타났다. 말소리장애 아동 중 음운인 식만 지연을 보이는 비율은 4 명(16\%), 어휘만 지연을 보이는 비율은 4 명(16\%), 어휘와 음운인식에서 함께 지연을 보이는 비율은 8 명(33\%) 으로 나타났으며 결과는 Figure 3과 같다.

\section{논의 및 결론}

본 연구는 음운발달 문제가 있는 아동의 음운인식과 어휘 특성

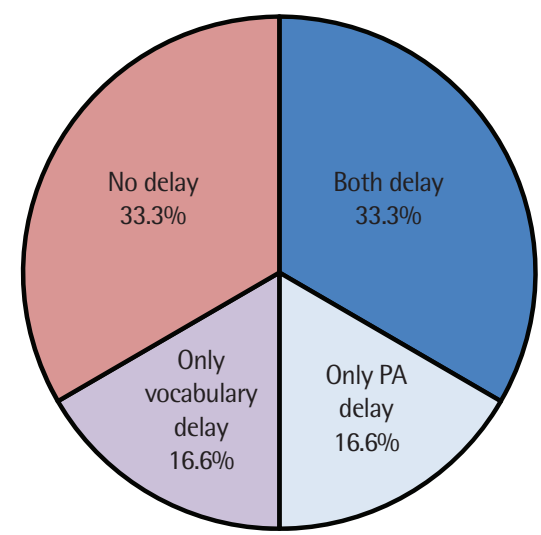

Figure 3. Rate of phonological awareness $(\mathrm{PA})$ and vocabulary delay.

을 살펴보기 위해 말소리장애 유무에 따른 집단간 차이 및 음운인 식, 어휘, 자음정확도 간의 상관관계를 분석하고, 말소리장애 아동 중 음운인식과 어휘발달 지연을 보이는 아동의 비율을 살펴보았다. 연구 결과에 따른 논의는 다음과 같다.

첫째, 말소리장애 아동은 연령에 따라 음운인식과 어휘 능력에 서 차이를 보였다. 일반적으로 아동의 연령이 증가함에 따라 성숙 의 효과로 인해 음운인식, 어휘 능력이 향상되며(Hong, Jeon, Pae, \& Lee, 2002; Liberman, Shankweiler, Fisher, \& Cater, 1974; Kim, \& Kim, 2006; Park, \& Choi, 2014) 이는 일반 아동뿐 아니라 말소리장 애 아동에게도 나타난다(McKinnon, McLeod, \& Reilly, 2007; St. Louis et al., 1992).

본 연구에서 말소리장애 아동 24 명 중 16 명(66\%)은 음운인식과 어휘 능력에서 모두 지연을 보이거나 음운인식 혹은 어휘 능력 각 각에서 어려움을 보였다. 말소리장애 아동의 음운인식 능력을 살펴 본 연구들은 말소리장애 아동이 음운인식에 지연을 보인다는 연구 (Anthony et al., 2011; Bird et al., 1995; Foy \& Mann, 2012; Gillon, 2002; Min, Lee, Choi, \& Choi, 2015; Nathan, Stackhouse, Goulandris, \& Snowling, 2004; Snowling et al., 2000; Webster, Plante, \& Couvilion, 1997)와 지연을 보이지 않는다는 연구(Lewis, Freebairn, Taylor, 2000; Snowling et al., 2000)로 상반된 결과를 제시하고 있다. 특 히 언어장애 동반 유무에 따라 말소리장애 아동의 음운인식 수행 이 다른데 언어장애를 동반한 말소리장애 아동은 음운인식에 지연 을 보이기도 하고(Catts, 1991; Hesketh, 2004; Lewis, \& Freebairn, 1992; Nathan et al., 2004; Snowling et al., 2000) 언어장애 동반 여 부와 상관없이 말소리장애만으로 음운인식에 지연을 보이기도 한 다(Gernand, \& Moran, 2007; Rvachew et al., 2003). 말소리장애 아 동의 음운인식 능력에 대해 연구 결과마다 차이를 보이는 이유는 
말소리장애 아동의 언어장애 동반 유무, 음운인식을 측정하는 과 제, 측정 방법 등에 기인할 수 있다. 또한 말소리장애 아동 집단의 음운인식점수 범위는 광범위하게 나타났는데 Shriberg, Austin, Lewis, McSweeny와 Wilson (1997)은 말소리장애와 언어장애를 동 시에 보이는 아동의 수행 평균과 범위가 다양하다는 것을 언급하 면서 연구마다 서로 다른 측정도구와 기준이 상이함을 그 이유로 제시하였다.

말소리장애 아동이 음운인식에 어려움을 보이는 이유에 대해서 말소리장애 아동은 단어를 개별적인 음소보다 전체로 인식하기 때 문에 단어에 포함된 개별 음소를 조작하는 데 어려움을 보일 수 있 고(Bird et al., 1995) 단어에 대한 음운정보에 접근하고 저장하는 데 결함을 보이기 때문으로 설명하기도 한다(Sutherland \& Gillon, 2005). Lewis 등(2000)은 말산출 문제가 음운에 의한 것이고 언어 장애를 동반하고 있는 아동의 경우 숙련된 음운인식과 읽기를 달 성하는 데에 실패할 위험이 크다고 주장하였다. 음운인식이 이후 문해 문제를 예측하고 예방하는 데 기여한다는 사실에는 큰 이견 이 없으며 이는 말소리장애 아동에게도 해당된다. 따라서 말소리장 애 아동이 음운인식에 어려움을 보이거나 더 나아가 이후 문해 기 술에 어려움을 보일 위험이 있다면 지속적인 모니터링과 차별적인 평가 및 중재가 요구된다. 음운인식에 지연을 보이는 말소리장애 아동을 대상으로 말소리 산출과 음운인식에 대한 중재를 적용했 을 때 더 나은 문해 기술을 입증한 연구도 있다(Gillon, 2002; Kirk \& Gillon, 2007; Kirk, Capri, Moore, \& Feusahrens, 2010). 말소리장 애 아동의 음운인식 및 어휘 수행과 관련된 요인으로 말소리의 오 류 패턴, 심각도가 고려되어야 한다(Leitao et al., 1997). 본 연구에 서는 이후 문해 기술과 관련되거나 예측할 수 있는 요인 중 음운인 식과 어휘 능력만을 살펴보았기 때문에 말소리장애의 지속 기간, 말소리 오류 패턴, 심각도와의 관계를 연구할 필요가 있겠다.

둘째, 음운인식, 어휘, 자음정확도 간에 상관관계가 나타났으며 특히 음운인식과 어휘 능력 간의 상관이 높은 것으로 나타났다. 음 운인식과 자음정확도 간의 관계는 아직 명확하지 않아 음운인식과 자음정확도 간의 관계에 대한 연구들은 상반된 결과를 제시하고 있다. 음운을 표현하는 능력과 음운인식 간의 긴밀한 상관관계가 있다는 연구도 있고(Bird et al., 1995; Bishop \& Adams, 1990; Larrivee \& Catts, 1999; McDowell et al., 2007) 음운인식과 자음정확 도 간의 상관관계를 찾을 수 없다는 연구도 있다(Gillon, 2005; Nathan et al., 2004; Rvachew \& Grawburg, 2006; Shin, Park, \& Seok, 2006). 본 연구에서는 음운인식과 자음정확도 간에 중간 정도(.44) 의 상관관계가 나타났는데 음운을 표현하는 능력이 부족한 아동 은 음운인식에서 어려움을 보일 수 있다는 것을 의미한다(Webster et al., 1997). 그러나 많은 연구에서 음운인식과 자음정확도의 상관 관계가 작거나 나타나지 않았는데 Overby, Trainin, Smit, Bernthal 과 Nelson (2012)은 말소리 산출 능력이 높으면 음운인식발달에 긍 정적인 영향을 미치는 것으로 나타났지만 연구들 간에 상이한 결 과를 보여주고 있으므로 관련된 매개 변수와의 관계를 파악하는 것이 중요하다고 하였다.

학령기 문해 기술에 영향을 미치는 요인 중 어휘와 음운인식 간 의 긴밀한 관계는 잘 알려져 있다(Cooper, Roth, Speece, \& Schatschneider, 2002; Metsala, 1999). 어휘집에 저장되어 있는 정보로부터 음운 규칙을 인출한다는 것을 가정했을 때 어휘 결함이 음운 산출 상의 어려움에 영향을 미칠 수 있고(Dodd, 2005) 어휘량이 많을수 록 더 다양한 말소리와 음절 구조를 산출할 수 있다(McCune \& Vihman, 2001). 어휘의 성장이 음운인식 능력에 영향을 미치기 때 문에(Walley, 1993) 수용어휘가 많은 아동은 음운인식 과제를 더 잘 수행할 수 있으며 6세의 수용언어가 8세의 음운인식을 가장 잘 예측해주기도 하였다(Olofsson \& Neidersoe, 1999). 음운인식과 수 용어휘 기술 간의 관련성은 말소리장애 아동에게도 나타났다(Rvachew \& Grawburg, 2006). 본 연구에서도 음운인식과 어휘 간에 강 한 상관관계(.68)가 나타났으며 말소리를 산출하는 능력보다 어휘 능력이 음운인식과 관련이 있다는 것을 확인할 수 있었다(Nathan et al., 2004).

셋째, 말소리장애 아동 24 명 중 8 명(33\%)이 음운인식과 어휘에 지연을 보였으며 4명(16\%)은 음운인식만 지연을 보이고 4명(16\%) 은 어휘에서만 지연을 보였다. 말소리장애 아동의 음운인식 지연 비 율을 살펴본 연구들은 20\%-93\%로 비교적 넒은 범위의 비율을 제 시하고 있다. Nathan 등(2004)은 추적조사를 통해 4, 5, 6세에 말소 리장애를 보였던 47 명의 아동이 6세 9개월이 되었을 때 읽기와 철 자 수행에서 어려움을 보이는 비율을 살펴보았을 때 말소리장애만 보였던 집단의 $47 \%$, 말소리장애와 언어장애를 함께 보였던 집단의 $68 \%$ 를 제시한 바 있다. 또한 Broomfield와 Dodd (2004)는 320명의 말소리장애 중 음운인식에 지연을 보이는 비율은 약 $70 \%$, 지연을 보이지 않는 비율을 $30 \%$ 로 제시하였다. 국내의 연구에서 Ko와 $\operatorname{Kim}$ (2010)은 20명의 말소리장애 아동 중 지연을 보이는 비율을 $40 \%$ 로 제시하였다. 본 연구에서 음운인식 지연 비율은 약 $50 \%$ 로 나타났으며 연구마다 비율의 차이를 보이는 이유는 대상 아동의 수와 연령, 음운인식 능력을 측정하는 방법(과제의 종류, 과제의 수 준), 음운인식 문제를 정의하는 기준 등 연구 방법에서의 차이에 기 인할 수 있다. 국내에서 말소리장애 아동의 음운인식 특성에 대해 많은 연구가 이루어 졌지만 구체적인 비율을 제시한 연구는 제한적 이다. 본 연구는 많은 음운인식과제 중 탈락과제만 사용하였고 음 
소 차원을 배제하였기 때문에 다른 연구들이 제시한 비율과 차이 가 나타났다고 할 수 있다. 또한 음운인식과 어휘에 문제를 보이지 않고 순수하게 말소리장애만을 보이는 비율이 24명 중 8명(33\%)으 로 나타났다. 따라서 음운인식과 어휘 문제의 동반 여부에 따라서 말소리장애 아동은 음운인식만 지연되는 경우, 음운인식과 어휘가 함께 지연되는 경우, 음운인식에 문제가 없는 경우 등의 이질적인 하위집단으로 나눌 수 있을 것이다.

본 연구는 말소리장애 아동의 이후 문해 기술에 영향을 미치는 요인으로 알려진 음운인식, 어휘, 자음정확도와의 관계를 살펴봄 으로써 말소리장애 아동이 동반하고 있는 문제의 특성을 확인하 고자 하였으며 동반하고 있는 문제에 따른 차별적인 평가와 중재의 필요성을 제안하였다. 임상 현장에서 말소리 문제로 의뢰되는 아동 들은 전형적으로 표준화된 조음 평가를 통해 문제를 보이는 음소 혹은 음운 오류 패턴에 대한 중재를 받는다. 그러나 본 연구의 결과 를 토대로 말소리장애 아동이 음운인식 및 어휘 능력에 지연을 보 인다면 이후 학령기에 나타날 수 있는 문해 기술의 문제를 예방하 기 위해 학령전기의 음운인식, 초기 문해 기술에 대한 직접적인 중 재와 지속적인 모니터링이 필요함을 시사한다. 본 연구에서는 말소 리장애의 문해 기술과 관련된 요인 중 음운인식과 어휘 능력을 살 펴보았는데 Lewis 등(2015)은 말소리장애의 지속성, 비언어성 지 능, 사회 경제적 지위(SES) 등도 영향을 미친다고 하였다. 따라서 말 소리장애 아동의 이후 문해 기술과 관련된 말소리 오류 패턴, 심각 도, 말소리장애의 지속성, 비언어성 지능, 사회 경제적 지위 등과 같 은 요인과의 관계를 살펴볼 필요가 있겠다.

\section{REFERENCES}

Anthony, J. L., Aghara, R. G., Dunkelberger, M. J., Anthony, T. I., Williams, J. M., \& Zhang, Z. (2011). What factors place children with speech sound disorders at risk for reading problems? American Journal of Speech-Language Pathology, 20, 146-160

Bernthal, J. E., Bankson, N. W., \& Flipsen, P. (2013). Articulation and phonological disorders: speech sound disorders in children (7th ed.). Boston, MA: Pearson.

Bird, J., Bishop, D. V., \& Freeman, N. H. (1995). Phonological awareness and literacy development in children with expressive phonological impairments. Journal of Speech, Language, and Hearing Research, 38, 446-462.

Bishop, D. V., \& Adams, C. (1990). A prospective study of the relationship between specific language impairment, phonological disorders and reading retardation. Journal of Child Psychology and Psychiatry, 31, 1027-1050.
Bradley, L., \& Bryant, P. E. (1983). Categorizing sounds and learning to read: a causal connection. Nature, 301, 419-421.

Broomfield, J., \& Dodd, B. (2004). The nature of referred subtypes of primary speech disability. Child Language Teaching and Therapy, 20, 135-151.

Burgess, S. R., \& Lonigan, C. J. (1998). Bidirectional relations of phonological sensitivity and prereading abilities: evidence from a preschool sample. Journal of Experimental Child Psychology, 70, 117-141.

Catts, H. W. (1991). Facilitating phonological awareness: role of speech-language pathologists. Language, Speech, and Hearing Services in Schools, 22, 196-203.

Catts, H. W. (1993). The relationship between speech-language impairments and reading disabilities. Journal of Speech, Language, and Hearing Research, $36,948-958$.

Cooper, D. H., Roth, F. P., Speece, D. L., \& Schatschneider, C. (2002). The contribution of oral language skills to the development of phonological awareness. Applied Psycholinguistics, 23, 399-416.

Dodd, B. (2005). Differential diagnosis and treatment of children with speech disorder (2nd ed.). Philadelphia, PA: Whur.

Forrest, K., Chin, S. B., Pisoni, D. B., \& Barlow, J. N. (1994). Talker normalization in normally articulating and phonologically delayed children: methodological considerations. Research on Spoken Language Processing, 19, 229-259.

Foy, J. G., \& Mann, V. (2001). Does strength of phonological representations predict phonological awareness in preschool children? Applied Psycholinguistics, 22, 301-325.

Foy, J. G., \& Mann, V. A. (2012). Speech production deficits in early readers: predictors of risk. Reading and Writing, 25, 799-830.

Gernand, K. L., \& Moran, M. J. (2007). Phonological awareness abilities of 6-year-old children with mild to moderate phonological impairments. Communication Disorders Quarterly, 28, 206-215.

Gillon, G. T. (2002). Follow-up study investigating the benefits of phonological awareness intervention for children with spoken language impairment. International Journal of Language \& Communication Disorders, 37, 381400.

Gillon, G. T. (2005). Facilitating phoneme awareness development in 3-and 4-year-old children with speech impairment. Language, Speech, and Hearing Services in Schools, 36, 308-324

Hemphill, L., \& Tivnan, T. (2008). The importance of early vocabulary for literacy achievement in high-poverty schools. Journal of Education for Students Placed at Risk, 13, 426-451. 
Hesketh, A. (2004). Early literacy achievement of children with a history of speech problems. International Journal of Language \& Communication Disorders, 39, 453-468.

Hong, S. I., Jeon, S. I., Pae, S., \& Lee, I. (2002). Development of phonological awareness in Korean children. Korean Journal of Communication Disorders, 7, 49-64.

Kim, M. J., Kim, S. J., Ha, J. W., \& Ha, S. (2015). A survey of co-morbidity and speech-language characteristics in speech sound disorders. Communication Sciences \& Disorders, 20, 446-455.

Kim, M. J., Pae, S., \& Park, C. I. (2007). Assessment of phonology for children (APAC). Incheon: Human Brain Research \& Consulting Co.

Kim, S. J., \& Kim, Y. T. (2006). Development of phonological awareness abilities of normal children in the age 5 and 6 through phonological elision task and its correlation to other phonological processing abilities. Korean Journal of Communication Disorders, 11, 16-28.

Kim, Y. T., Hong, G. H., Kim, K. H., Jang, H. S., \& Lee, J. Y. (2009). Receptive \& expressive vocabulary test (REVT). Seoul: Seoul Community Rehabilitation Center.

Kirk, C., \& Gillon, G. T. (2007). Longitudinal effects of phonological awareness intervention on morphological awareness in children with speech impairment. Language, Speech, and Hearing Services in Schools, 38, 342-352.

Kirk, C., Capri, G., Moore, H., \& Feusahrens, M. (2010). Improving the efficiency of intervention for preschoolers with SSD. Poster presented at the Annual Convention of the American Speech Language Hearing Association, Philadelphia, PA.

Ko, Y. K., \& Kim, S. J. (2010). A comparison of phonological awareness and reading ability between children with and without functional articulatory and phonological disorders. Korean Journal of Communication Disorders, $15,157-167$.

Larrivee, L. S., \& Catts, H. W. (1999). Early reading achievement in children with expressive phonological disorders. American Journal of Speech-Language Pathology, 8, 118-128.

Leitao, S., Hogben, J. H., \& Fletcher, J. (1997). Phonological processing skills in speech and language impaired children. European Journal of Disorders of Communication, 32, 91-111.

Leitao, S., \& Fletcher, J. (2004). Literacy outcomes for students with speech impairment: long-term follow-up. International Journal of Language and Communication Disorders, 39, 245-256.

Lewis, B. A., \& Freebairn, L. (1992). Residual effects of preschool phonology disorders in grade school, adolescence, and adulthood. Journal of Speech,
Language, and Hearing Research, 35, 819-831.

Lewis, B. A., Freebairn, L. A., \& Taylor, H. G. (2000). Follow-up of children with early expressive phonology disorders. Journal of Learning Disabilities, $33,433-444$.

Lewis, B. A., Freebairn, L. A., \& Taylor, H. G. (2002). Correlates of spelling abilities in children with early speech sound disorders. Reading and Writing, 15, 389-407.

Lewis, B. A., Freebairn, L., Tag, J., Ciesla, A. A., Iyengar, S. K., Stein, C. M., \& Taylor, H. G. (2015). Adolescent outcomes of children with early speech sound disorders with and without language impairment. American Journal of Speech-Language Pathology, 24, 150-163.

Liberman, I. Y., Shankweiler, D., Fischer, F. W., \& Carter, B. (1974). Explicit syllable and phoneme segmentation in the young child. Journal of Experimental Child Psychology, 18, 201-212.

Lonigan, C. J., Burgess, S. R., Anthony, J. L., \& Barker, T. A. (1998). Development of phonological sensitivity in 2-to 5-year-old children. Journal of Educational Psychology, 90, 294-311.

McCune, L., \& Vihman, M. M. (2001). Early phonetic and lexical development: a productivity approach. Journal of Speech, Language, and Hearing Research, 44, 670-684.

McDowell, K. D., Lonigan, C. J., \& Goldstein, H. (2007). Relations among socioeconomic status, age, and predictors of phonological awareness. Journal of Speech, Language, and Hearing Research, 50, 1079-1092.

McKinnon, D. H., McLeod, S., \& Reilly, S. (2007). The prevalence of stuttering, voice, and speech-sound disorders in primary school students in Australia. Language, Speech, and Hearing Services in Schools, 38, 5-15.

Metsala, J. L. (1999). Young children's phonological awareness and nonword repetition as a function of vocabulary development. Journal of Educational Psychology, 91, 3-19.

Metsala, J. L., \& Walley, A. C. (1998). Spoken vocabulary growth and the segmental restructuring of lexical representations: precursors to phonemic awareness and early reading ability. In J. L. Metsala \& L. C. Ehri (Eds.), Word recognition in beginning reading (pp. 89-120). Mahwah, NJ: Erlbaum.

Min, J. H., Lee, K. J., Choi, S. H., \& Choi, C. H. (2015). Phonological awareness and writing ability of school aged children with and without speech sound disorders. Journal of Speech, Language \& Hearing Disorders, 24, 225236.

Munson, B., Edwards, J., \& Beckman, M. E. (2005). Phonological knowledge in typical and atypical speech-sound development. Topics in Language Disorders, 25, 190-206. 
Nathan, L., Stackhouse, J., Goulandris, N., \& Snowling, M. J. (2004). The development of early literacy skills among children with speech difficulties: a test of the critical age hypothesis. Journal of Speech, Language, and Hearing Research, 47, 377-391.

Oh, G. A., Seo, E. Y., Ko, Y. K., \& Kim. S. J. (2016). A screening test of phonological awareness for 4, 5, 6 year-old children. Proceedings of the 2016 Fall Conference of Korean Society of Speech Sciences, 191-192.

Olofsson, A., \& Niedersoe, J. (1999). Early language development and kindergarten phonological awareness as predictors of reading problems: from 3 to 11 years of age. Journal of Learning Disabilities, 32, 464-472.

Overby, M. S., Trainin, G., Smit, A. B., Bernthal, J. E., \& Nelson, R. (2012). Preliteracy speech sound production skill and later literacy outcomes: a study using the Templin Archive. Language, Speech, and Hearing Services in Schools, 43, 97-115.

Park, B. R., \& Choi, Y. L. (2014). The relationship among visual perception ability, phonological awareness ability and reading ability in 4- to 5-yearold children. Journal of Speech \& Hearing Disorders, 23, 91-103.

Preston, J. L., Hull, M., \& Edwards, M. L. (2013). Preschool speech error patterns predict articulation and phonological awareness outcomes in children with histories of speech sound disorders. American Journal of SpeechLanguage Pathology, 22, 173-184.

Preston, J., \& Edwards, M. L. (2010). Phonological awareness and types of sound errors in preschoolers with speech sound disorders. Journal of Speech, Language, and Hearing Research, 53, 44-60.

Rvachew, S. (2007). Phonological processing and reading in children with speech sound disorders. American Journal of Speech-Language Pathology, $16,260-270$.

Rvachew, S., \& Grawburg, M. (2006). Correlates of phonological awareness in preschoolers with speech sound disorders. Journal of Speech, Language, and Hearing Research, 49, 74-87.
Rvachew, S., Ohberg, A., Grawburg, M., \& Heyding, J. (2003). Phonological awareness and phonemic perception in 4-year-old children with delayed expressive phonology skills. American Journal of Speech-Language Pathology, 12, 463-471.

Shin, H. J., Park, H. J., \& Seok, D. I. (2006). The relationship between phonological awareness abilities and articulation correctness in preschool children aged from 4 to 6. Communication Disorders, 29, 51-59.

Shriberg, L. D., Austin, D., Lewis, B. A., McSweeny, J. L., \& Wilson, D. L. (1997). The Speech Disorders Classification System (SDCS) extensions and lifespan reference data. Journal of Speech, Language, and Hearing Research, 40, 723-740.

Snowling, M., Bishop, D. V. M., \& Stothard, S. E. (2000). Is preschool language impairment a risk factor for dyslexia in adolescence? Journal of Child Psychology and Psychiatry and Allied Disciplines, 41, 587-600.

St. Louis, K. O., Ruscello, D. M., \& Lundeen, C. (1992). Coexistence of communication disorders in schoolchildren. ASHA Monographs, 27, 1-57.

Sutherland, D., \& Gillon, G. T. (2005). Assessment of phonological representations in children with speech impairment. Language, Speech, and Hearing Services in Schools, 36, 294-307.

Torgesen, J. K., Wagner, R. K., \& Rashotte, C. A. (1994). Longitudinal studies of phonological processing and reading. Journal of Learning Disabilities, $27,276-286$

Walley, A. C. (1993). The role of vocabulary development in children's spoken word recognition and segmentation ability. Developmental Review, 13, 286-350.

Webster, P. E., Plante, A. S., \& Couvillion, L. M. (1997). Phonologic impairment and prereading: update on a longitudinal study. Journal of Learning Disabilities, 30, 365-375.

Yopp, H. K. (1988). The validity and reliability of phonemic awareness tests. Reading Research Quarterly, 23, 159-177. 
Appendix 1. 음운인식선별검사

\section{1. 연습단계}

(1) 아동에게 ‘꽃’ 그림과 ‘병’ 그림을 보여주고 합하여 ‘꽃병’을 말하게 한다.

(2) 아동이 반응한 후 검사자는 “꽃’ 그림을 가린 후, "이번에는 꽃병에서 ‘꽃’을 빼고 말해보세요.”라고 지시한다.

(3) 이 절차를 ‘종이컵(종이와 컵 그림)', ‘딸기우유(딸기와 우유 그림)’에서 반복한다.

(4) 아동이 실패했을 경우, 검사자는 적절한 반응을 알려준다.

\section{2. 검사단계}

1) 음운인식 검사 지시문

"자 이제 선생님이 단어를 들려줄 거에요. 잘 듣고 선생님이 빼라는 소리를 빼고 말해주세요"

2) 음운인식 검사 요령

(1) 검사자는 목표낱말을 읽어준 뒤, 밑줄 친 부분을 빼고 각각의 검사항목을 말하게 한다.(예: 야구방망이에서 /야구/를 빼고 말해보세요)

(2) 검사항목은 그림을 사용하지 않고 실패해도 피드백을 주지 않는다.

(3) 연속해서 5 개 문항에서 실패하면 검사를 종료한다.

\section{3. 채점 요령}

1) 검사자는 아동의 반응을 정반응 $(+)$, 오반응(-)으로 기입한다.

2) 총 20 개의 문항 중 맞게 반응한 항목의 수를 세어 원점수로 계산한다.

3) 조음에 오류가 있지만 각 검사항목에 맞게 정반응 하였다면 맞는 것으로 채점한다.

\begin{tabular}{|c|c|c|c|c|c|c|c|c|}
\hline \multicolumn{9}{|c|}{ 음운인식검사 채점지 } \\
\hline \multicolumn{2}{|c|}{ 이름(ID): ( } & \multicolumn{2}{|c|}{ ), 생년월일(연령): ( } & ), 성 & \multicolumn{2}{|c|}{ 검사일: } & \multicolumn{2}{|c|}{, 검사자: } \\
\hline \multicolumn{9}{|c|}{ 음운인식 검사 항목 } \\
\hline & 검사항목 & 반응 & & 검사항목 & 반응 & & 검사항목 & 반응 \\
\hline 1 & 야구방망이 & & 8 & 비옷 & & 15 & 휴지통 & \\
\hline 2 & 동전지갑 & & 9 & 창문 & & 16 & 호랑이 & \\
\hline 3 & 손톱깎이 & & 10 & 놀이터 & & 17 & 축구공 & \\
\hline 4 & 소고기 & & 11 & 코끼리 & & 18 & 유리창 & \\
\hline 5 & 책가방 & & 12 & 수요일 & & 19 & 오토바이 & \\
\hline 6 & 신발장 & & 13 & 풍선 & & 20 & 안녕하세요 & \\
\hline 7 & 물총 & & 14 & 바지 & & & 총점 & $/ 20$ \\
\hline
\end{tabular}




\section{국문초록}

\section{말소리장애 아동의 음운인식과 어휘 특성}

서은영 ${ }^{*}$ 고유경 ${ }^{1} \cdot$ 오경아 ${ }^{1} \cdot$ 김수진 ${ }^{2}$

${ }^{1}$ 나사렛대학교 일반대학원 언어치료학과, ${ }^{2}$ 나사렛대학교 언어치료학과

배경 및 목적: 말소리장애 아동은 동반하고 있는 문제가 다양한 이질적인 집단이다. 특히 말소리장애 아동이 동반하고 있는 문제 중 언 어, 어휘, 음운인식의 문제는 이후 문해 기술을 예측하고 문제를 예방하는 데 중요한 요인이다. 따라서 본 연구는 말소리장애 아동의 문 해 기술과 관련된 음운인식과 어휘 특성을 살펴보고 음운인식, 어휘, 자음정확도 간 상관관계를 살펴보고 말소리장애 아동이 음운인 식과 어휘에서 지연을 보이는 비율을 살펴보고자 하였다. 방법: 일반 아동과 말소리장애 아동 각각 24 명씩을 대상으로 말소리, 음운인 식, 어휘 능력을 평가하였다. 결과: 연령과 말소리장애 유무에 따라 음운인식, 어휘 능력에 유의미한 차이가 나타났으며, 음운인식이 자 음정확도보다 어휘 능력과 더 큰 상관을 보였다. 말소리장애 아동 중 음운인식과 어휘에서 모두 지연을 보이는 비율은 $33 \%$, 음운인식만 지연을 보이는 비율은 $16 \%$, 어휘만 지연을 보이는 비율은 $16 \%$, 순수한 말소리장애의 비율은 $33 \%$ 로 나타났다. 논의 및 결론: 말소리장 애 아동이 동반하고 있는 문제의 특성을 확인하고 차별적인 평가와 중재의 필요성을 제안하였다.

핵심어: 말소리장애 아동, 음운인식, 어휘, 문해 기술

\section{참고문헌}

고유경, 김수진(2010). 기능적 조음음운장애아동과 일반아동의 음운인식과 읽기능력의 비교 및 상관. 언어청각장애연구. 15, 157-167. 김민정, 김수진, 하지완, 하승희(2015). 말소리장애의 동반장애 유형 및 말-언어 특성에 관한 설문조사. 언어청각장애연구, 20, 446-455. 김민정, 배소영, 박창일(2007). 아동용 발음평가(APAC). 인천: 휴브알엔씨.

김선정, 김영태(2006). 음운생략과제를 통한 5-6세 아동의 음운인식 발달 및 음운처리 능력과의 상관도 연구. 언어청각장애연구, 11, 16-28. 김영태, 홍경훈, 김경희, 장혜성, 이주연(2009). 수용·표현어휘력검사(REVT). 서울: 서울장애인종합복지관. 민종현, 이경재, 최성희, 최철희(2015). 학령기 말소리장애 아동과 일반 아동의 음운인식 및 쓰기능력. 언어치료연구, 24, 225-236. 박보라, 최예린(2014). 4-5세 일반 아동의 초기 읽기 능력과 시지각 및 음운인식 능력 간 관련성. 언어치료연구, 23, 91-103. 신혜정, 박희정, 석동일(2006). 한국 4-6세 아동의 음운인식 발달과 자음정확도 간의 상관관계 연구. 난청과 언어장애, 29, 51-59. 오경아, 서은영, 고유경, 김수진(2016). 4, 5, 6세 아동을 위한 음운인식 선별검사 개발. 한국음성학회 가을학술대회발표논문집, 191-192. 홍성인, 전세일, 배소영, 이익환(2002). 한국 아동의 음운인식 발달. 언어청각장애연구, 7, 49-64. 